\title{
The Role of "Long-Term" and "New" Injectors in a Declining HIV/AIDS Epidemic in Rio de Janeiro, Brazil ${ }^{\sharp, \dagger}$,
}

\author{
MARIANA A. HACKER, ${ }^{1}$ SAMUEL R. FRIEDMAN, ${ }^{2}$ \\ PAULO ROBERTO TELLES, ${ }^{3}$ \\ SYLVIA LOPES TEIXEIRA, ${ }^{4}$ VERA BONGERTZ, ${ }^{4}$ \\ MARIZA G. MORGADO ${ }^{4}$ AND \\ FRANCISCO INÁCIO BASTOS ${ }^{1}$
}

${ }^{1}$ Department of Health Information, Oswaldo Cruz Foundation, Rio de Janeiro, Brazil

${ }^{2}$ National Development Research Institutes, Inc., New York City, New York, USA

${ }^{3}$ Rio de Janeiro Harm Reduction Project, State University of

Rio de Janeiro, Rio de Janeiro, Brazil

${ }^{4}$ Department of Immunology, Oswaldo Cruz Foundation,

Rio de Janeiro, Brazil

\begin{abstract}
Background. A substantial decline of HIV prevalence has been observed in injection drug users (IDUs) from Rio de Janeiro, in recent years. Differential characteristics and behaviors of new (injecting for $<6$ years) and long-term $(>=6 y)$ injectors may help to understand recent changes and to implement appropriate prevention strategies.
\end{abstract}

\#This article is based on the data and experience obtained during the WHO Drug Injection Study Phase II-a project coordinated and sponsored by the World Health Organization and implemented by the WHO Phase II Drug Injection Collaborative Study Group. A full list of all collaborative investigator is presented in the main reports of the study (WHO, 2002).

${ }^{\dagger}$ The authors alone are responsible for the views expressed in this article, which do not necessarily represent those of the other investigators participating in the WHO Drug Injection Study Phase II or the views or policy of the World Health Organization.

$\$$ A Report from the WHO Drug Injection Study Phase II.

Address correspondence to Francisco Inácio Bastos, DIS/CICT Fundação Oswaldo Cruz (FIOCRUZ), Av. Brasil 4365, Biblioteca de Manguinhos \# 209, Rio de Janeiro 21045900, Brazil. E-mail: bastos@cict.fiocruz.br 
Methods. Between October 1999 and December 2001, 609 active/ex-IDUs were recruited from different communities, interviewed, and tested for HIV. Contingency table analysis and t-tests were used to assess differences between new and long-term injectors. Multiple logistic regression was used to identify independent predictors of HIV serostatus for long-term and new injectors.

Results. HIV prevalence was $11.7 \%$ for 309 long-term injectors (95\% CI 8.115.3 ) and $4.3 \%$ for 300 new injectors (95\% CI 2.0-6.6). New injectors reported having engaged in treatment and having received syringes from needle exchange programs (NEPs) more frequently than long-term injectors in the last 6 months, but sharing behaviors remained frequent and even increased vis-à-vis long-term injectors. For male new injectors, "sexual intercourse with another man" was found to be the sole significant risk factor for HIV infection (Adj OR $=8.03$; 95\% CI 1.52-42.48). Among male long-term injectors, "to have ever injected with anyone infected with HIV" (Adj OR=3.91; 95\% CI 1.09-14.06) and to have "ever been in prison" (Adj $O R=2.56 ; 95 \%$ CI 1.05-6.24) were found to be significantly associated with HIV infection.

Discussion. New injectors are seeking help in drug treatment centers or needle exchange programs. They differ from long-term injectors in terms of their risk factors for HIV infection and have lower prevalence levels for HIV. Such differences may help to understand the recent dynamics of HIV/AIDS in this population and highlight the need to reinforce new injectors' help-seeking behavior and to reduce current unacceptably high levels of unprotected sex and syringe sharing in new injectors despite attendance of prevention/treatment programs.

Keywords HIV, AIDS, new injectors, prevention, WHO drug injection study phase II

\section{Introduction}

The HIV/AIDS epidemic is a major public health challenge worldwide. UNAIDS estimates that 5 million new cases occurred in 2001, over $95 \%$ of them in low- and middle-income countries (UNAIDS, 2002). Injection drug users (IDUs) have had a key role in the spread of HIV/AIDS worldwide. Health and social harms related to drug injecting are of serious concern in many different developing and transitional countries.

The WHO Drug Injection Study Phase II is a multicity study of injecting drug use carried out in cities in Argentina, Brazil (three sites), Belarus, China, Colombia, Iran, Kenya, Malaysia, Nigeria, Russian Federation, Ukraine, Vietnam, Bangkok, and New York. It was designed to provide policy and decision makers with comprehensive and reliable information for intervention development on injecting drug use and its health consequences by conducting rapid assessments linked with behavioral and seroprevalence (HIV, heptatitis B and C) surveys among injection drug users.

Since the middle 1980s, IDUs have had a pivotal role in the Brazilian AIDS epidemic, with a peak in the late 1980s/early 1990s (Brazilian Ministry of Health, 2002a; Lowndes et al., 2000). While HIV/AIDS in injection drug users seem to be decreasing in recent years in the southeast, where Brazilian major metropolitan areas such as Sao Paulo and Rio de Janeiro are located (Bastos et al., 2002a; Mesquita et al., 2001a), the epidemic has been progressing unabated in southern Brazil in IDUs, their sexual partners, and offspring (Bastos et al., 2002b, c). Whereas in the Santos Metropolitan Area (Sao Paulo, southeast), HIV point prevalence among IDUs declined from 65 to 42\%, from 1994-1996 to 1999 (Mesquita et al., 2001), HIV point prevalence in Porto Alegre (Rio Grande do Sul, south) increased from $48 \%$ in 1998 (Caiaffa et al., 2003) to $77 \%$ in 2000 (Caiaffa et al., 2002) in the same 
population. Whereas HIV incidence among cocaine users was found to be 5.3/100 persons-year at risk in a cohort study in Porto Alegre (Pechansky et al., 2003), it was estimated to be 0.71 in a sample of cocaine users with similar characteristics from Sao Paulo (Turchi et al., 2002).

In the three Brazilian cities with serial cross-sectional surveys in the 90scurrently engaged in WHO Phase II Study: Rio de Janeiro (Rio de Janeiro state, southeast), Santos (Sao Paulo state, southeast), and Salvador (Bahia state, south of northeastern region) - a consistent decline has been observed in infection rates for different blood-borne infections (hepatitis B and C, HTLV-I/II, and HIV infection) (Bastos et al., 2002a; Dourado et al., 2002; Mesquita et al., 2001a).

Different types of evidence corroborate the observed decline of HIV seroprevalence in injectors from Rio de Janeiro in recent years, including zero incidence in a previous study using a sensitive/less sensitive ("detuned") HIV assay protocol (Guimaraes et al., 2001) and substantial declines in the prevalence of hepatitis B and, especially, of hepatitis C, from a previous (1994-96) to the current (2000-2001) cross-sectional study (Alberti et al., 2001). The proportion of AIDS cases registered among IDUs in Rio de Janeiro was less than $2 \%$ of the total AIDS cases reported in the state in 2000, whereas in 1992 it was 7\% (Brazilian Ministry of Health, 2002b). A recent drug treatment survey carried out in the two major centers in Rio de Janeiro also found a very low HIV prevalence for drug users, including those with a history of injection (Bastos et al., 2000).

There is a considerable literature on long-term and new injectors in terms of their infection rates for different blood-borne pathogens, and their respective risk factors and protective behaviors (Chitwood et al., 2001; Des Jarlais et al., 1999; Friedman et al., 1998, 1989; Fuller et al., 2002; Neaigus et al., 1996; Gyarmathy et al., 2002). With a single exception (Friedman et al., 1998), no previous analyses assessing new and long-term injectors were carried out in Brazil. Key risk factors for HIV infection among new injectors include high injecting/sharing frequencies and networking with high-risk injectors (Des Jarlais et al., 1999; Neaigus et al., 1996). Recent findings highlighted other risk factors contributing to the further spread of HIV among new injectors, such as a history of commercial sex and violence victimization (Fuller et al., 2002).

New injectors were found to be less conscious about HIV/AIDS and more frequently engaged in risky practices. New injectors often report that they attend preventive programs less frequently than long-term injectors (Friedman et al., 1989; Neaigus et al., 1996). Despite such high frequency of risk behaviors and poor adherence to preventive programs, most studies have found lower prevalences for HIV among new injectors (compared to long-term injectors), probably due to the fact that long-term injectors have more injection years of potential exposure. Some analyses have shown that new injectors normally share injection equipment and practice unprotected sex with people from social networks with low background prevalences for different blood-borne infections (Friedman et al., 1998), although this may be less true for female new injectors (Friedman et al., 1999). A review by Friedman et al. (1994) highlighted the interplay of individual and ecological dimensions of HIV/AIDS among new and long-term injectors in different contexts. In cities with high seroprevalence and low seroincidence (mature epidemics), longterm injectors are less likely to seroconvert because of saturation, while in cities with both high seroprevalence and high seroincidence (epidemics not yet stabilized), 
seroconversion among new injectors tend to hold their seroconversion rates below those of long-term injectors.

Recent studies have found low prevalence and high incidence rates in young injectors due to the persistence of high levels of risk behaviors in this population (Garfein et al., 2002; Miller et al., 2002). For reasons still unclear, a recent study found an excess of risk behavior without increased risk of seroconversion for hepatitis B and C in young injectors (Hagan and Thiede, 2002).

We assess here sociodemographic and behavioral characteristics of long-term and new injectors in the context of a declining epidemic in Rio de Janeiro, Brazil.

\section{Methods}

\section{Recruitment}

Drug users were recruited from October 1999 to December 2001 from different communities of Rio de Janeiro. The targeted communities were defined after a comprehensive effort of interviewing key informants and drug users from different communities using in-depth interviews and focus groups, according to WHO guidelines. A team of outreach workers and a mobile unit (van) were used to recruit potential interviewees and to bring them back and forth to the assessment center located downtown. After attending training workshops, outreach workers worked in the very communities in which they were recruited. Outreach workers had a sociodemographic profile similar to the interviewees themselves, sharing most of their habits and mores. Probably due to deep mutual trust (something especially valued in communities plagued by police raids and drug-dealers wars) and the fact that the project provided comprehensive referral to different preventive and care initiatives, no drug user contacted in the community refused to answer the questionnaire and to perform the blood exams.

A concentrated efforts was made to recruit people as representative of the diversity of Rio de Janeiro social geography as possible. No drug users were recruited from treatment centers, but the sample included a small proportion (17\%) of interviewees currently engaged in drug treatment programs (for a period not exceeding 1 month, as defined by the Study inclusion criteria). Among the drug users with a history of drug injection, $273(45 \%)$ reported to have injected at least once in the last 6 months while $336(55 \%)$ were defined as former injectors (ex-IDUs), i.e., reporting no injection of illicit drugs in the last 6 months.

Questionnaire and Informed Consent. The study was preceded by translation and adaptation of the original English form, developed by WHO and the Survey Coordinating Center, in New York City. The survey was preceded by two pilot studies. The study protocol, questionnaire, and consent form were approved by FIOCRUZ IRB (Human Subjects Protection Committee) and complied with Brazilian and international guidelines. Volunteers were compensated for their effort, receiving a modest amount ( US \$10) for travel and snack.

The different sections of the questionnaire address sociodemographic information, drug using and sexual habits, drug injection-related risks and harms, and sociomedical history (including assessment of violence and overdoses). 
Testing. After signing informed consent and answering the questionnaire, volunteers were asked to donate $30 \mathrm{~mL}$ of whole blood. Blood samples were sent to two laboratories at Oswaldo Cruz Foundation (AIDS and Molecular Immunology Laboratory and the Reference Center for Viral Hepatitis). The results presented here refer exclusively to HIV serological testing following WHO protocol guidelines.

To define HIV infection for the purposes of the present study, all samples were tested using two ELISA tests (Vironosticva HIV Uni-Form II plus O, Organon, Boxtel, NL, and Ortho HIV-1/HIV-2 Ab-Capture ELISA Test System, Ortho, New Jersey, USA), with different principles, and confirmed by IFA (BiomanguinhosFIOCRUZ, BR), as defined by the Brazilian Ministry of Health flowchart. Results were delivered to interviewees in individual sessions of posttest counseling.

Data Analysis. Injecting time was calculated for current injectors by subtracting the age they reported to have injected for the first time from their current age. For ex-injectors, injecting time was calculated subtracting the age they reported they had injected for the first time from the age they reported that they had injected for the last time.

Separate analyses were carried out using 7 (median value) and 6 years of continuous injection practices to distinguish "long-term" and "new" injectors. Since exploratory analyses found similar results for the two different cut-offs, we defined 6 years as the cut-off point, making current analyses comparable to previous literature.

Contingency table analysis (Yates corrected chi-square or Fisher exact test) and $t$-tests were used to assess differences between new and long-term injectors. Significance level was defined as $p<0.05$. Multiple logistic regression was used to identify independent predictors of HIV serostatus for long-term and new injectors. In the selection of the variables for multivariate analyses, statistical (a significant or borderline association with the outcome) and epidemiological (plausibility and consistency) criteria were used. No interactions remain in the final logistic models.

\section{Results}

Sociodemographic information and sexual and injecting behaviors of new and longterm injectors are presented in Table 1.

New injectors were more likely to report being single and living alone or in households other than theirs than long-term injectors. New injectors also reported having fewer children than long-term injectors. Most of these differences can be explained by the fact long-term and new injectors belong to different birth cohorts (as confirmed by age-stratified analyses; data not shown), with long-term injectors being significantly older than new injectors (means $=36.7$ vs. $27.5 \mathrm{y} ; p=0.000$ ). New injectors were more frequently of white race/ethnicity than long-term injectors.

Many differences can be found between long-term and new injectors' drug use. New injectors have used fewer alcohol and cigarettes in the last 6 months (compared to long-term injectors). Long-term injectors reported to have more frequently injected outside the city where they live than new injectors, in the last 2 years $(21.7 \%$ vs. $13.7 \% ; p=0.013)$. Due to the very definition of both categories, long-term injectors reported to have injected more times than new injectors during their druginjecting careers, with over half $(54 \%)$ of the former reporting an accumulated number of injections greater than 100 shots. 
ORDER

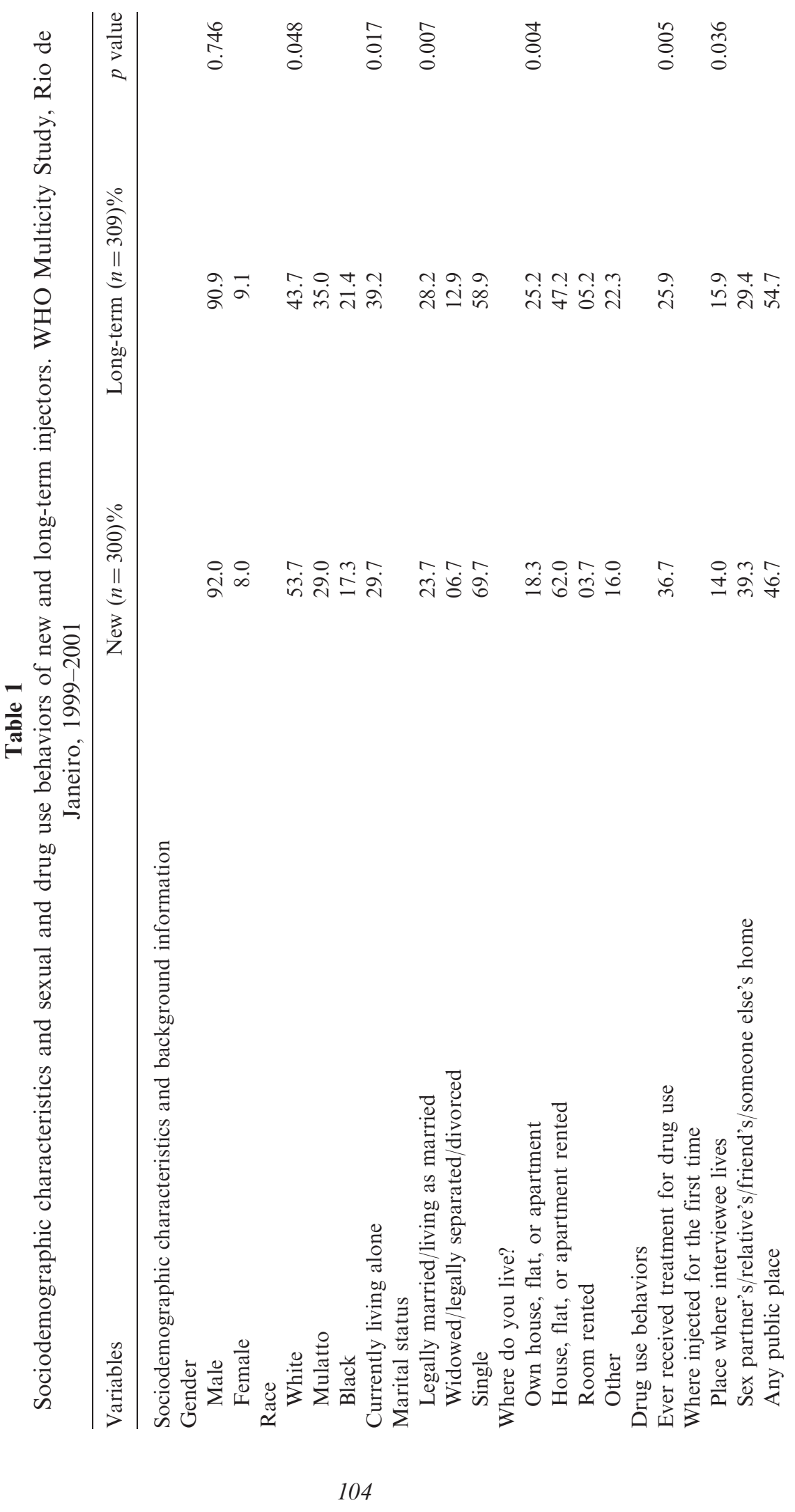




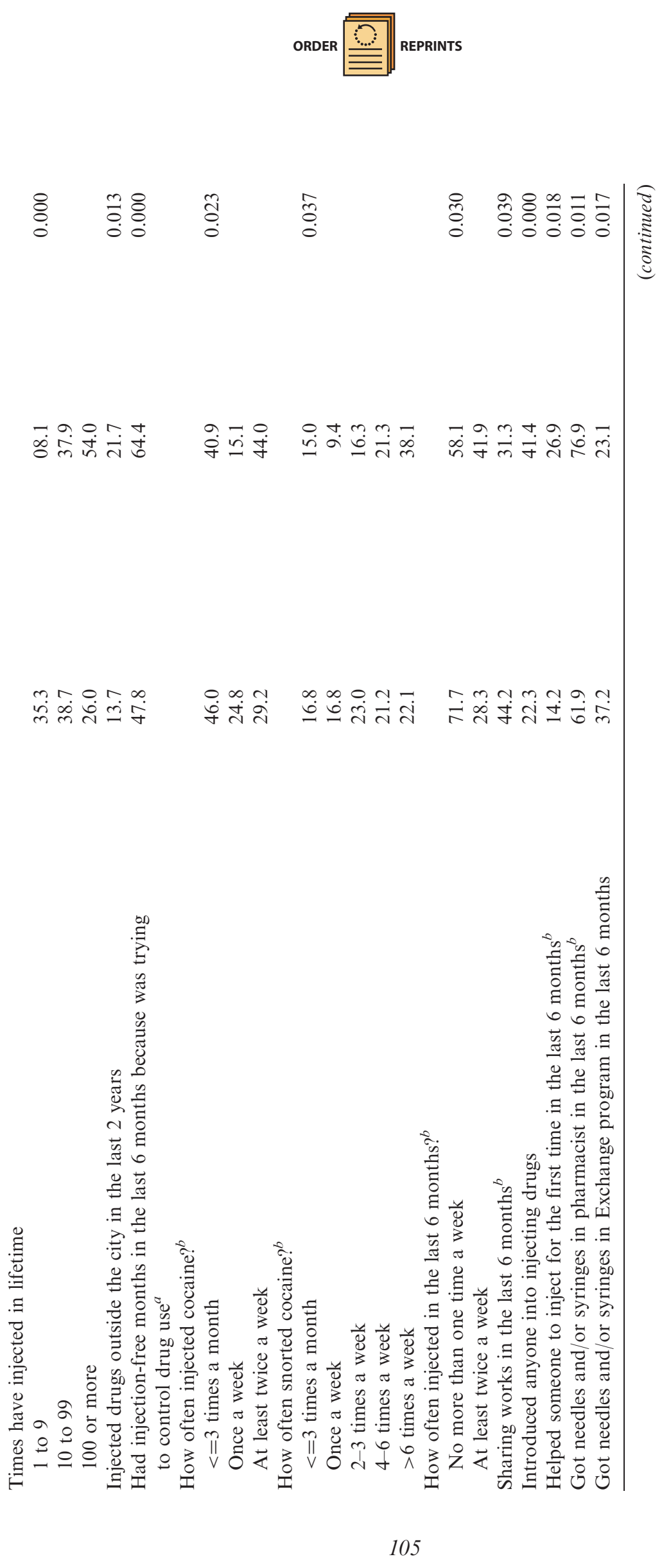


ORDER





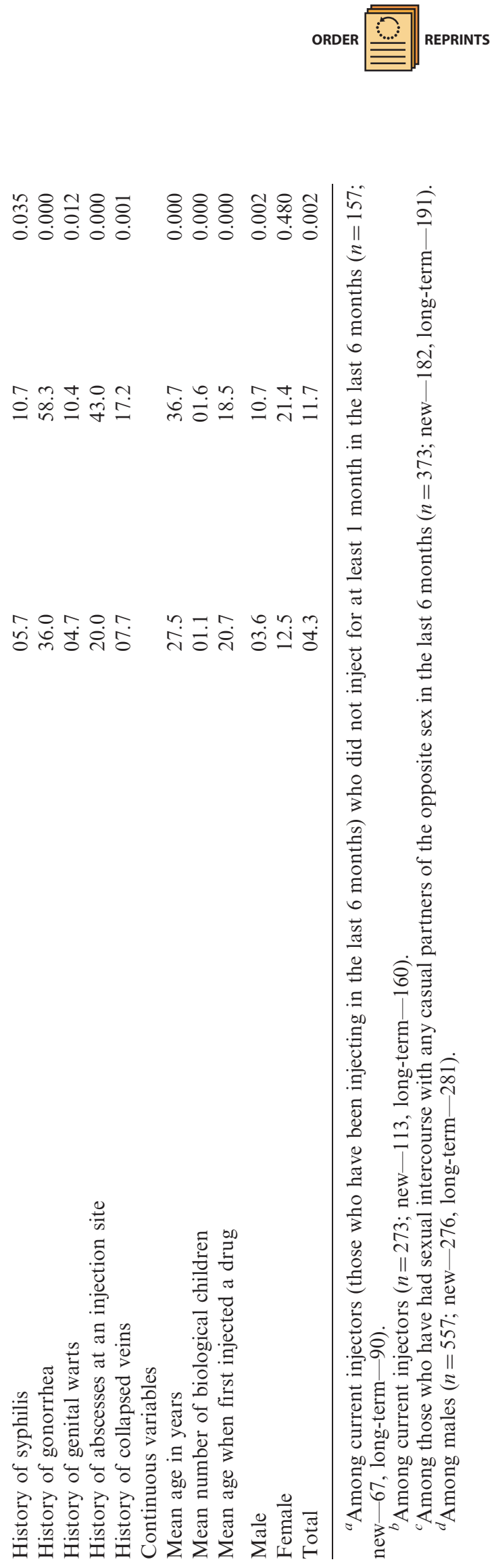
Among current injectors, the overall injecting frequencies were higher among longterm injectors. For both injected cocaine $(44.0 \%$ vs. $29.2 \% ; p=0.023)$ and any injectable drug $(41.9 \%$ vs. $28.3 \% ; p=0.030)$, a higher proportion of long-term injectors (compared to new injectors) reported injecting drugs at least twice every week. Cocaine snorting was also higher among long-term injectors. On the other hand, long-term injectors reported more frequent attempts to control their drug injecting habits in the last 6 months $(64.4 \%$ vs. $47.8 \% ; p=0.000)$.

Of special concern is the fact that among interviewees currently injecting, more new injectors shared needles and/or syringes than long-term injectors $(44.2 \%$ vs. $31.3 \% ; p=0.039)$. On the other hand, new injectors were more likely to use needle exchange programs (NEPs) as a key source of clean needles and syringes than were long-term injectors $(37.2 \%$ vs. $23.1 \% ; p=0.017)$. For both long-term and new injectors, however, pharmacies were the most frequent source of sterile syringes (there is no prescription law in Brazil).

More long-term injectors reported having initiated someone into injecting $(41.4 \%$ vs. $22.3 \% ; p=0.000)$ and helping someone to inject $(26.9 \%$ vs. $14.2 \%$; $p=0.018$ ), compared to new injectors. For both the first and most recent injections, new injectors were less likely to report having injected in their own home, injecting rather in someone's else home.

Some auspicious behavioral changes were reported by new injectors: they have more frequently entered treatment for drug use than long-term injectors $(36.7 \%$ vs. $25.9 \% ; p=0.005)$, and have started to inject not as young as long-term injectors did (means $=20.7$ vs. $18.5 \mathrm{y} ; p=0.000$ ).

Despite the fact that long-term injectors were more likely to have known someone with AIDS before injecting for the first time, behavior change toward safer behaviors after having heard about HIV/AIDS was more likely among new injectors (66.2\% vs. $56.2 \% ; p=0.014)$.

Long-term injectors were more likely to have never used condoms with casual partners in the last 6 months $(39.3 \%$ vs. $23.6 \% ; p=0.002)$ and were more likely to have had male-to-male sex in the last 5 years $(39.1 \%$ vs. $29.7 \% ; p=0.024)$. Data for the use of condoms in male-to-male sex is available for the last 6 months before interview. A substantial proportion of those intercourses were unprotected for both long-term $(56.7 \%)$ and new injectors $(42.9 \%)$.

New injectors described their health status more favorably than long-term injectors. Consistently, long-term injectors were more likely to report a variety of medical conditions, including sexually transmitted diseases (syphilis, gonorrhea, genital warts), injuries related to nonhygienic injecting practices (collapsed veins and abscesses), and tuberculosis.

HIV prevalence among new injectors (4.3\%; 95\% CI: 2.01-6.59) was significantly lower than among long-term injectors (11.7\%; 95\% CI: 8.12-15.28).

Due to the small number of female injectors, bivariate and multivariate analyses were carried out only for the male subsample. Table 2 presents key variables associated with HIV infection in bivariate analyses for new and long-term injectors, respectively. Associations significant at the level of 0.05 are discussed as follows.

For new injectors, "Living alone" (OR = 5.94), "Self-defined homo/bisexual identity" (OR = 9.25), "Injected with used needles and/or syringes from a relative who was not a primary sex partner" $(\mathrm{OR}=20.00)$, "Had sexual intercourse with another man in the last 5 years" $(\mathrm{OR}=10.38)$, and "Age when injected for the very first time" (OR = 1.09) were associated with higher probability of HIV infections. 




Marcel Dekker, INC. 

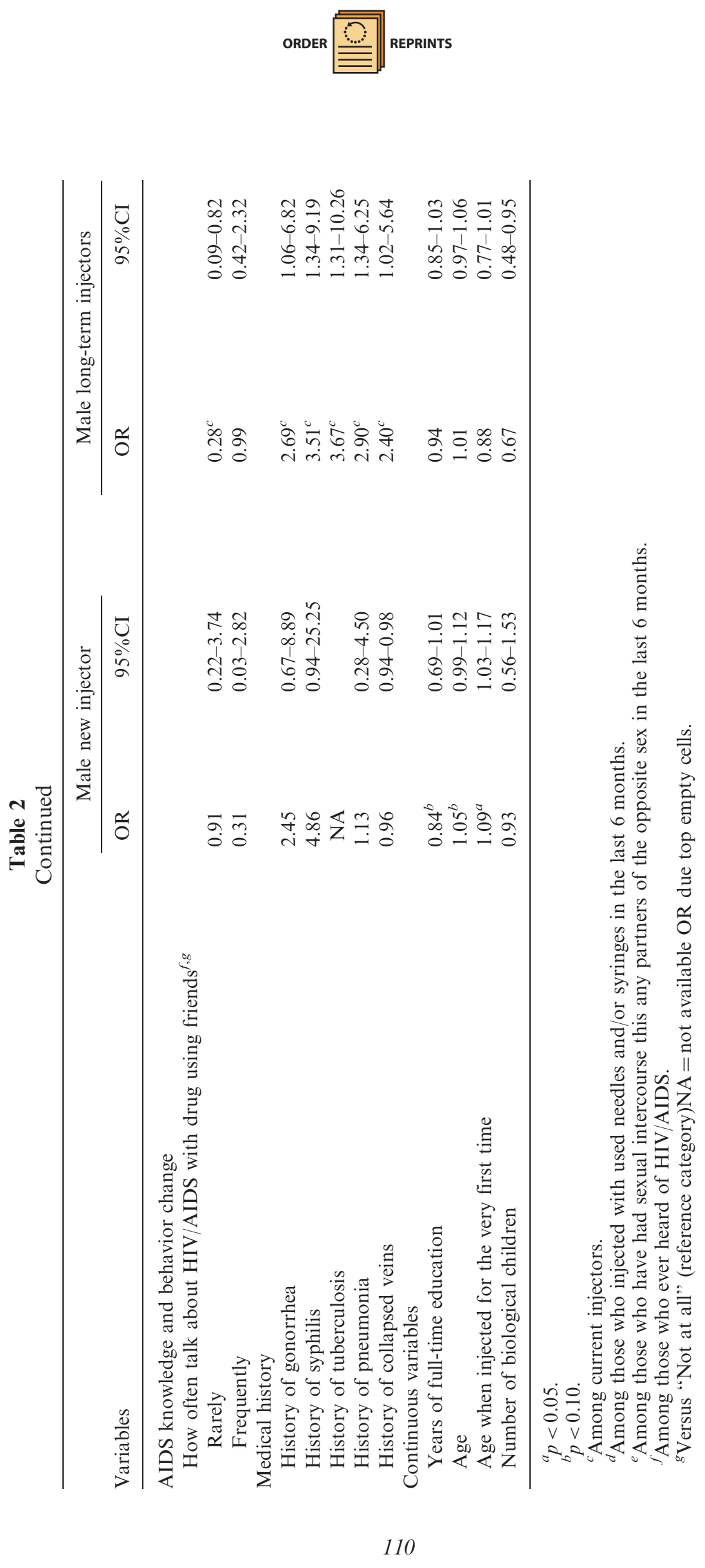
Among long-term injectors, to consider him/herself to be homo/bisexual $(\mathrm{OR}=4.36)$ and "Living alone" $(\mathrm{OR}=2.34)$ were found to be associated with HIV infection. As expected, to have "Ever injected with anyone infected with HIV" $(\mathrm{OR}=5.38)$ and to have "Ever been in prison" $(\mathrm{OR}=3.10)$ were found to be associated with HIV. To have had "Sexual intercourse with a primary partner of the opposite sex in the last 6 months" $(\mathrm{OR}=0.30)$ and "Injected with used needles and/ or syringes from a close friend" $(\mathrm{OR}=0.15)$ were inversely associated with HIV infection.

We explored further the putative protective role of a report of "Sexual intercourse with a principal partner from opposite sex in the last 6 months" for male long-term injectors. We found interviewees without principal partners (PP) in the last 6 months reported significantly more frequently (than those with PP) to have had sexual intercourse with occasional partners, from both sexes, with most of those sexual acts being unprotected (data not shown). Different medical conditions reported by interviewees: syphilis $(\mathrm{OR}=3.51)$, gonorrhea $(\mathrm{OR}=2.69)$, tuberculosis $(\mathrm{OR}=3.67)$, and pneumonia $(\mathrm{OR}=2.90)$ were found also to be associated with HIV infection.

Table 3 presents risk factors, with respective adjusted odds-ratios, independently associated with the outcome (HIV infection) as found in the final logistical models for new and long-term male injectors. For male new injectors, "Sexual intercourse with another man in the last 5 years" was found to be the sole significant risk factor for HIV infection (AdjOR $=8.03$; 95\% CI 1.52-42.48).

Among male long-term injectors: to have "Ever injected with anyone infected with HIV" (AdjOR = 3.91; 95\% CI 1.09-14.06) and to have "Ever been in prison" (AdjOR $=2.56 ; 95 \%$ CI $1.05-6.24$ ) were found to be significantly associated with HIV infection.

\section{Discussion}

In the present study, new injectors seem to be seeking help in drug treatment centers and needle exchange programs. On the other hand, the high levels of needle and/or syringe sharing by new injectors are of special concern. Even considering that new injectors may selectively network with partners and acquaintances with relatively low background seroprevalences, exposure to different blood-borne pathogens tend to increase as years of unsafe injecting behaviors accumulate. New injectors have begun to inject at older ages than long-term injectors and have been injecting at lower frequencies vis-á-vis long-term injectors. In a study carried out in New York, new injectors were also more likely to have started injecting at an older age but no differential in overall injection frequencies was observed (Des Jarlais et al., 1999).

Long-term injectors seem to function in our sample as the "living memory" of drug injecting networks, initiating and helping drug users in transition from other routes to start injecting. A recent study carried out in Baltimore, Maryland found that among young short-term IDUs, having two or more "trainers" before being able to self-inject was associated with higher HIV infection rates (Doherty et al., 2000). The fact that most new injectors from our study report having injected for both the first and last time in someone's else home reinforces the potential importance of social networks in the initiation and maintenance of injection 
ORDER



112 
behaviors and the role of experienced injectors in such networks (Friedman and Aral, 2001).

Different harms have been mentioned by long-term injectors recruited by our study, probably due to the fact that risks for different medical conditions accumulate over time and can be further aggravated by persistent harmful injecting habits. Harms and diseases frequently mentioned by long-term injectors included overdoses (experienced by themselves and/or their peers) and a variety of medical conditions, including sexually transmitted infections (STIs), HIV (as documented by test results), conditions commonly associated with nonhygienic injection (abscesses and collapsed veins), and diseases associated with unhealthy environments and/or immunodeficiency, e.g., tuberculosis. Similar high prevalences for different diseases in long-term injectors have been described in Brazilian (Carvalho et al., 1996; Mesquita et al., 2001b) and international (CDC (Centers for Diseases Control and Prevention), 2001; Riley et al., 2002) literature.

New and long-term injectors differ substantially in their respective risk factors for HIV infection. In a former paper by our group (Souza et al., 2002), use of crack and powder cocaine was found to be associated with unprotected anal sex. In the present analysis, "Sexual intercourse with another man in the last 5 years" (mostly unprotected) was found to be a key risk factor for HIV for male new injectors. International studies highlight the double risks and high infection rates for HIV and other STIs still faced by gay and bisexual IDUs, after two decades of the HIV/AIDS epidemic (Bluthenthal et al., 2001; Maslow et al., 2002). New injectors recruited by the present study started to inject in a period when the Brazilian AIDS epidemic was no longer driven by HIV-infected gay and bisexual men, but rather by heterosexual men and women (Bastos et al., 2001; Brazilian Ministry of Health, 2002a). One must observe, however, that the observed decline in the number of AIDS cases in Brazilian gay and bisexual men must not be translated into complacency vis-á-vis renewed risks.

A history of ever having been in prison or jail was found to be a risk factor for HIV infection in male long-term injectors, probably reflecting the fact that prisons housed subjects with previous risky and harmful injection practices, some of them unexplored by our analyses (Choopanya et al., 2002; Estebanez et al., 2002), and represent a setting where new infections take place due to harsh living conditions, favoring nonhygienic injection practices and unprotected sexual intercourse. Evidence for parenteral transmission of HIV inside Brazilian prisons was recently published (Burattini et al., 2000).

Brazilian prevention initiatives in this field have been tentative, comprising, for instance, tuberculosis screening, prophylaxis, and treatment (Ferreira et al., 1996), but not the exchange of injection equipment. Brazilian prisons should implement comprehensive programs aiming to reduce drug-related harm and sexual transmission of HIV and other STIs in the prison environment (Dolan et al., 2003).

In sum, risk factors differ in new and long-term injectors in our study, due to individual, generational, and contextual factors. As shown by Friedman et al. (1995), risk factors can differ in high and low seroprevalence contexts. New and long-term injectors of the present study have not only significantly different seroprevalences for HIV, but have been injecting in quite distinct drug scenes and networks since their first injection took place. Such differences may help to understand the recent dynamics of HIV in injection drug users in Rio de Janeiro, where a substantial decline of HIV infection rates (Guimaraes et al., 2001; Telles et al., 1997) and high HIV-1 specific immune response have been observed (Bongertz et al., 2003). 
New injectors are starting to inject at older ages and inject less frequently than long-term injectors, postponing their chances to be infected by parenteral route. The balance between decreasing frequencies of injection and higher levels of sharing by new injectors should be further evaluated. New injectors' help-seeking behavior should be reinforced, but current preventive and therapeutic initiatives must be improved, helping to reduce unacceptably high levels of unprotected sex and syringe sharing in new injectors.

Increases in sexually transmitted infection rates and in risky sexual activities have been recently reported in different homosexual populations (CDC (Centers for Disease Control and Prevention), 1999; Van de Ven et al., 2000). The current study points to male-to-male unprotected sex as a key risk factor for new injectors. Such finding merits further analyses and call for the renewal of current preventive strategies targeting gay and bisexual injectors.

Our study has many limitations. Random samples cannot be drawn from an unknown universe, especially for behaviors that are not only hidden and stigmatized but also criminalized. To minimize such biases, the survey was integrated with a thorough assessment of Rio de Janeiro drug scenes using in-depth interviews, focus groups, and mapping. In accordance with the strategies of targeted sampling (Watters and Biernacki, 1989), we tried to assess as many communities as possible, with a mobile team of outreach workers. Nonetheless, it is not possible to generalize our findings for the population of injection drug users from Rio de Janeiro.

Another limitation refers to sample size. Although the sample/size was much larger than the minimum number of 200 active and 100 ex-IDUs suggested by WHO study guidelines, some differences could not be made evident due to insufficient statistical power. The small number of female drug injectors enrolled in the study precluded analyses for this subgroup. Former studies age consistently shown a small number of women have been injecting in Rio de Janeiro (Bastos et al., 2000; Guimaraes et al., 2001; Telles et al., 1997). From a complementary perspective, the small number of female commercial sex workers injecting cocaine $(22 / 697)$ in the city of Santos, Sao Paulo did not permit further evaluation of the association of cocaine injection and HIV infection in this population (Szwarcwald et al., 1998).

Cross-sectional studies cannot define causality, since risk factors and outcomes are obtained simultaneously. Some authors have questioned the reliance of selfreported information, but recent papers have shown this to be quite reliable (Petry, 2001).

To partially address these limitations, we carried out a thorough assessment of laboratory markers of recent/old HIV infection (i.e., sensitive/less sensitive "detuned" HIV assay protocol) and different blood-borne infections, to be analyzed in future studies.

Finally, the project spent a long time ( $\sim 26$ months) to effectively recruit a sizeable number of IDUs from different communities, in successive turns, making the sample subjected to seasonal variations. The extended period was necessary to obtain a diverse and large enough sample in a huge and markedly heterogeneous city.

\section{Acknowledgment}

The project in its different phases and components was funded by the Oswaldo Cruz Foundation/Brazilian Ministry of Health, the Rio de Janeiro State Research Council 
(FAPERJ) and the National Research Council (CNPq), and the World Health Organization (WHO). SRF was supported by the US National Institute on Drug Abuse grants R01 DA03574 (Risk Factors for AIDS Among Intravenous Drug Users) and R01 DA13128 (Networks, Norms and HIV Risk Among Youth).

\section{Resumen}

Introducción. Se ha observado un descenso notable de la prevalencia del VIH en los usuarios de drogas inyectables (UDIs) de Río de Janeiro en los últimos años. Las características y los comportamientos específicos de los nuevos (uso de drogas inyectables $<6$ años) y antiguos (uso de drogas inyectables $>=6$ años) UDIs pueden ayudar a la comprensión de los recientes cambios y a la implementación de estrategias de prevención adecuadas. Métodos. Se han convocado, entrevistado y probado para el VIH, 609 ex-UDIs/UDIs en actividad de diferentes comunidades entre 10/1999 y 12/2001. Se han utilizado análisis de tables de contingencia y testes $t$ para evaluar las diferencias entre los nuevos y antiguos UDIs. Se ha utilizado una regressión logística multivariada para identificar predictores de la infección por el VIH entre nuevos e antiguos UDIs. Resultados. La prevalencia para el VIH ha sido de $11.7 \%$ para los 309 antiguos UDIs (95\% IC 8.1-15.3) y de $4.3 \%$ para los 300 nuevos UDIs (95\% IC 2.0-6.6). Los nuevos UDIs han relatado estar bajo tratamiento y haber recibido jeringas en Programas de Cambio de Jeringas (PTS), en los últimos 6 meses, con mayor frecuencia que los antiguos, sin embargo el uso compartido de jeringas ha sido más frecuentemente relatado por los nuevos UDIs. Entre los nuevos UDIs del sexo masculino, se ha identificado la "relación sexual con otro varón" como el único factor de riesgo independiente para la infección por el VIH $(\mathrm{AOR}=8.03 ; 95 \% \mathrm{IC} 1.52-42.48)$. Entre los antiguos UDIs del sexo masculine "haberse inyectado con alguien infectado por el VIH" (AOR $=3.91$; 95\% IC 1.0914.06) y "haber sido preso" ( $\mathrm{AOR}=2.56$; 95\% IC 1.05-6.24) se mostraran independientemente asociados a la infección por el VIH. Discusión. Los nuevos UDIs demandaran los centros de tratamiento para las drogas y PTS. Ellos difieren de los antiguos con relación a los factores de riesgo para la infección por el VIH e tienen niveles más bajos de prevalencia para el VIH. Esas diferencias ayudan a comprender la dinámica reciente del VIH/SIDA en ese grupo y apuntan para la necesidad de reforzar la búsqueda de tratamiento y de reducir los niveles elevados de sexo desprotegido y uso compartido de jeringas entre los nuevos UDIs, a pesar de su participación en programas de tratamiento y prevención.

\section{Résumé}

Introduction. La prevalence du VIH a diminue de facon important chez les utilisateurs de drogue par injection (UDI) de Rio de Janeiro depuis les dernieres annees. Les differences de characteristiques et de comportments a risque entre injecteurs recents $(<6$ annees de injection) et de longue date $(>=6)$ peuvent aider a expliquer ces changements et a implementer des strategies de preventions adequates. Methodes. 609 UDI (ex/actifs) ont ete recrutes de different 
communautes, interviewes et testes pour le VIH entre entre octobre 1999 et decembre 2001. Des tableaux de contingeance et t-tests ont ete utilises pour comparer injecteurs recents et de longue date. Des analyses logistiques multivariees ont ete utilisees pour identifier des les facteurs de risque independement associe avec le statut VIH dans chaque groupe d' injecteurs. Resultats. La prevalence du VIH etait de $11.7 \%$ (95\% IC 8.1-15.3) pour les 309 injecteurs de longue date et $4.3 \%$ (95\% IC 2.0-6.6) pour les 300 injecteurs recents. Les injecteurs recents rapportaients avoir commence des traitements et obtenu des seringues des programmes d'echange (PES) plus souvent que les injecteurs de longue date dans les derniers 6 mois, bien que leurs habitudes de partage soient demeurees frequentes, et meme augmentees comparativement aux injecteurs de longues dates. Chez les hommes, les relations sexuelles avec d'autres hommes etaient le seul facteur de risque associe avec le statut de VIH chez les injecteurs recents (ORaj $=8.03 ; 95 \%$ IC $1.52-42.48)$. Parmi les injecteurs de longue date, «avoir deja injecte arec un seropositif》 (ORaj=3.91; 95\% IC: 1.09 14.06) et《avoir deja ete en prison》 (ORaj:2.56; 95\% IC 1.05-6.24) etaient significativement associes avec le status de VIH. Discussion. Les injecteurs recents semblent chercher de 1'aide dans les centers de traitement d'UDI ou dans les PES. Leurs facteurs de risque sont differents de ceux des injecteurs de longue date et leur prevalence du VIH plus faible. Les differences entre injecteurs recents et de longue date peuvent aider a expliquer la recente dynamique du VIH/AIDS chez les UDI. Elles mettent egalement en evidence le besoin de favoriser les comportements de recherche d'aide afin de diminuer la frequence elevee de relations sexuelles nonprotegees et de partage de seringues parmi les injecteurs recents, meme parmi ceux participant aux programmes de prevention et traitement.

\section{Resumo}

Introdução. Um declínio substancial da prevalência do HIV vem sendo observado em usuários de drogas injetáveis (UDI) do Rio de Janeiro nos últimos anos. As características e os comportamentos específicos de novos (uso de drogas injetáveis $<6$ anos) e antigos (uso de drogas injetáveis $>=6$ anos) UDIs podem ajudar a entender as recentes mudanças e a implementar estratégias de prevenção apropriadas. Métodos. Entre 10/1999 e 12/2001, 609 ex-UDIs/UDIs em atividade foram recrutados de diferentes comunidades, entrevistados e testados para o HIV. Análises de tabelas de contingência e testes $t$ foram utilizados para avaliar as diferenças entre novos e antigos UDIs. A regressão logistica multivariada foi utilizada para identificar preditores da infecção pelo HIV entre novos e antigos UDIs. Resultados. A prevalência de HIV foi de $11.7 \%$ para os 309 antigos UDIs (95\% IC 8.1-15.3) e 4.3\% para os 300 novos UDIs (95\% IC 2.0-6.6). Os novos UDIs relataram engajamento em tratamento e terem recebido seringas em Programas de Trocas de Seringas (PTS), nos últimos 6 meses, com maior freqüência do que os antigos, porém o compartilhamento de seringas foi mais freqüentemente relatado pelos novos UDIs. Para os novos UDIs masculinos a "relação sexual com outro homem" foi identificada como o único fator independente de risco para a infecção pelo HIV (AOR = 8.03; 95\% IC 1.52-42.48). Entre os antigos UDIs masculinos "ter injetado com alguém infectado pelo HIV" (AOR = 3.91; 95\% IC 1.09-14.06) e "ter sido preso" $(\mathrm{AOR}=2.56 ; 95 \% \mathrm{IC} 1.05-6.24)$ se mostraram independentemente 
associados à infecção pelo HIV. Discussão. Os novos UDIs demandaram os centros de tratamento para drogas e PTS. Eles diferem dos antigos em relação aos fatores de risco para a infecção pelo HIV e apresentam níveis mais baixos de prevalência para o HIV. Estas diferenças ajudam a compreender a dinâmica recente do HIV/AIDS nesta população e apontam para a necessidade de reforçar a procura por tratamento e reduzir os níveis elevados de sexo desprotegido e compratilhamento de seringas entre os novos UDIs, a despeito de sua participação em programas de tratamento e prevenção.

\section{The Authors}

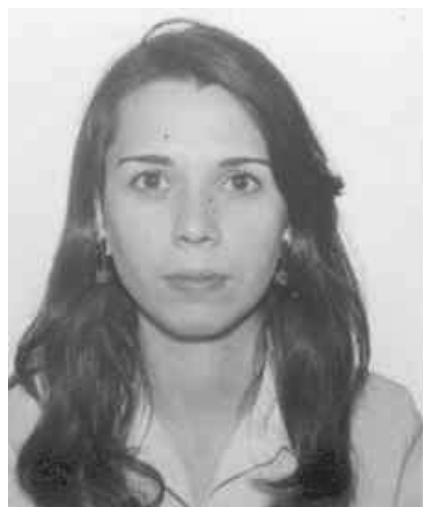

Mariana A. Hacker, MPH, (Brazil) graduated in statistics in 2000, taking additional courses in physics. She joined Oswaldo Cruz Foundation (FIOCRUZ) Health Information Department (DIS-CICT) as a trainee in June 2000 and applied in the same year for the FIOCRUZ MPH course. She started her MPH course in 2001, working as a statistician of the WHO Drug Injection Study Phase II. The present article is part of her dissertation. Francisco I. Bastos, local coordinator of the WHO Study, was her dissertation advisor. Both have been working on such database in cooperation with the other Brazilian co-authors and with Sam Friedman, senior researcher, from

New York. Currently, the DIS-CICT/FIOCRUZ team has been dedicated to the analysis of Brazilian major databanks in the field of HIV/AIDS, in cooperation with the Imperial College, UK, profiting also from a formative grant from NIH, USA.



Samuel R. Friedman, Ph.D., (USA) is a Senior Research Fellow and the Director of the Social Theory Core in the Center for Drug Use and HIV Research at National Development and Research Institutes, Inc., New York City. Dr. Friedman is an author of over 300 publications on HIV, STI, and drug use epidemiology and prevention. His substantive areas of expertise include sociobehavioral science, social epidemiology, HIV interventions, and drug users' organizations. 


\section{8}
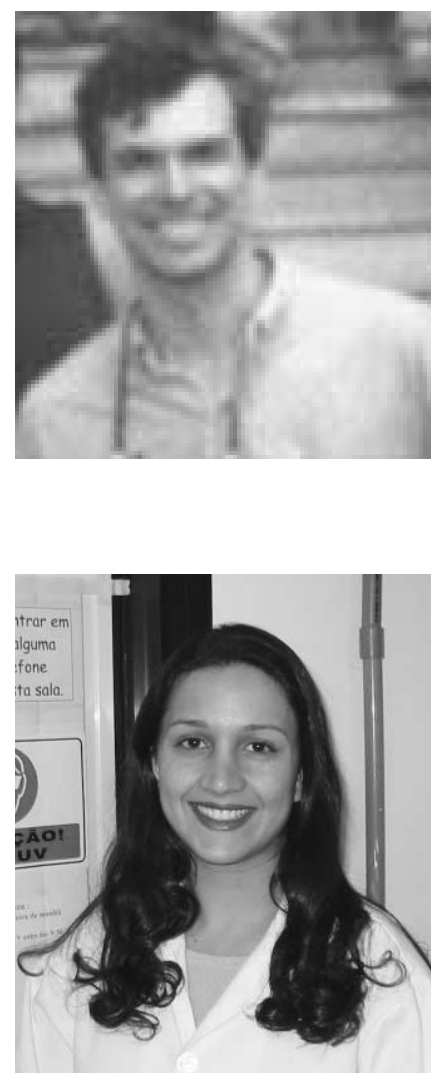

\section{A. Hacker et al.}

Paulo Roberto Telles, M.D., Ph.D., (Brazil) is Head of the Rio de Janeiro Harm Reduction Project, State University of Rio de Janeiro. Dr. Telles is a clinical psychiatrist and epidemiologist, with a Ph.D. in Biomedical Engineering. His dissertation assessed HIV spread in different Brazilian regions, using spatial-temporal modeling.

Sylvia Lopes Teixeira, M.Sc., (Brazil) received her M.Sc. in Molecular Biology in 2002 and is currently a Ph.D. student at the Oswaldo Cruz Foundation. Her main areas of interest are HIV diversity and resistance to antiretroviral medicines. Her former M.Sc. dissertation, advised by Mariza G. Morgado and Francisco I. Bastos, received an award delivered by the Rio de Janeiro Research Council.

Vera Bongertz, Ph.D., (Brazil) is a senior researcher at the Laboratory of AIDS and Molecular Immunology, Department of Immunology, Oswaldo Cruz Foundation. She has published extensively on neutralizing antibodies, HIV diversity, and the immunology of mother-to-child transmission of HIV.

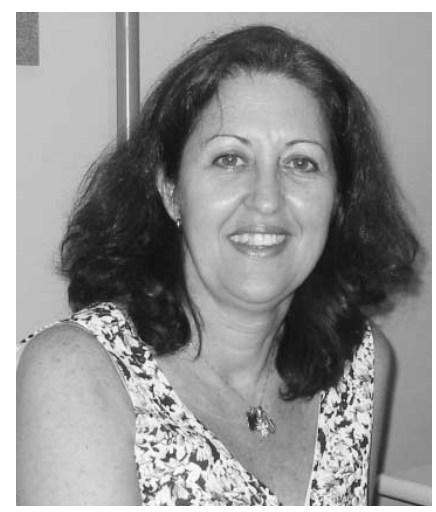

Mariza G. Morgado, Ph.D., (Brazil) is the Head of the Laboratory of AIDS and Molecular Immunology, Department of Immunology, Oswaldo Cruz Foundation. She has published extensively in the field of HIV diversity, resistance to antiretroviral medicines, and coinfections. She is currently a member of the Brazilian AIDS Advisory Board and the Brazilian AIDS Vaccines Taskforce. 


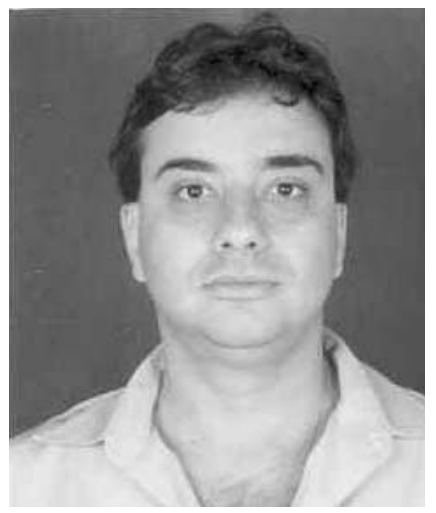

Francisco Inácio Bastos, M.D. Ph.D., (Brazil) is a senior researcher at the Department of Health Information, Oswaldo Cruz Foundation Dr. Bastos is an author of over 100 papers and book chapters on the epidemiology and prevention of HIV, blood-borne infections, and drug use. He has also been working as an editor of books and supplements, including a special issue of the Brazilian journal Cadernos de Saúde Pública on HIV/AIDS epidemiology and two special issues of International Journal of Drug Policy, the latter a comprehensive assessment of needle exchange programs worldwide.

\section{References}

Alberti, S., Hacker, M., Custodio Miguel, J., Oliveira, M. L., Bastos, F. I. (2001). Can viral hepatitis be kept under control among injection drug users? Lessons from the field, in Rio de Janeiro, Brazil. Virus Rev. Res. 6(suppl. 1):109.

Bastos, F. I., Lowndes, C. M., Castello-Branco, L. R., Linhares-de-Carvalho, M. I., Oelemann, W., Bernier, F., Morgado, M. G., Yoshida, C. F., Rozental, T., Alary, M. (2000). Sexual behaviour and infection rates for HIV, blood-borne and sexually transmitted infections among patients attending drug treatment centers in Rio de Janeiro, Brazil. Int. J. STD. AIDS 11(6):383-392.

Bastos, F. I., Telles, P. R., Hacker, M. (2001). Uma década de pesquisas sobre usuários de drogas injetáveis and HIV/AIDS no Rio de Janeiro. Parte I: "Rumo a uma epidemia sob controle?" Ministéro da Saúde ed. A Contribuição dos Estudos Multicentricos frente á Epidemia de HIV/AIDS entre UDIs no Brasil. Série Avaliação 8, Brasilia: Ministério da Saúde, pp. 49-78.

Bastos, F. I., Mesquita, F. C., Andrade, T., Telles, P. R., Bueno, R., Dourado, M. I., Hacker, M., Piconez, D., Farias, A. H., WHO Multicity Study Brazilian Group. (2002a). In Declining HIV/AIDS epidemics among IDUs from 3 Brazilian main metropolitan areas. Book of Abstracts. In: Stimson, G., ed. In: XII International Conference on the Reduction of Drug Related Harm; Ljublijan, Slovenia, March 3-7, 2002; UK: IHRA, A672, 150 pp.

Bastos, F. I., Pina, M. F., Szwarcwald, C. L. (2002b). The social geography of HIV/ AIDS among injection drug users in Brazil. Int. J. Drug Policy 13(2):137-144.

Bastos, F. I., Derrico, M., Veloso, V. G., Nielsen, K., Morgado, M. G., Pilotto, J. H., João, E., Grinsztejn, B., Kreitchmann, R., Fonseca, R., Riegel, B., Busch, B., Bryson, Y. (2002c). In Risk factors for HIV among late-presenting pregnant women in Porto Alegre (POA), southern, and Rio de Janeiro ( $R J)$, southeastern Brazil. In: Gatell, J. M., Casabona, J., eds. Abstract Book vol. II. In: XIV International AIDS Conference; Barcelona, Spain, July 7-12. Barcelona: Fundació Barcelona SIDA 2002/IAS, July105WePeC6090.

Bluthenthal, R. N., Kral, A. H., Gee, L., Lorvick, J., Moore, L., Seal, K., Edlin, B. R. (2001). Trends in HIV seroprevalence and risk among gay and bisexual men who inject drugs in San Francisco, 1988 to 2000. J. Acquir. Immune Defic. Syndr. 28(3):264-269. 
Bongertz, V., Ouverney, E. P., Maia-Teixeira, S., Silva-de-Jesus, C., Morgado, M. G., Hacker, M. A., Bastos, F. I., The Brazilian Network for HIV Isolation and Characterization. (2003). Anti-human immunodeficiency virus-1 antibody titers in injecting drug users compared to sexually infected individuals. Mem. Inst. Oswaldo Cruz 98(2):209-212.

Brazilian Ministry of Health (2002a). Epidemiologic Bulletin. http://www.aids. gov.br/final/biblioteca/bol_set_2001/boletim.htm (accessed March 2003).

Brazilian Ministry of Health. (2002b). http://www.aids.gov.br (accessed March 2003).

Burattini, M., Massad, E., Rozman, M., Azevedo, R., Carvalho, H. (2000). Correlation between HIV and HCV in Brazilian prisoners: evidence for parenteral transmission inside prison. Rev. Saude Publica 34(5):431-436.

Caiaffa, W. T., Proietti, F. A., Mingotti, S. A., Carneiro-Proietti, A. B., Doneda, D., Gandolfie Projecto Aude-Brasil I e II. (2002). A dinâmica da epidemia do HIV: Considerações empíricas e teóricas-O caso dos usuários de drogas injetáveis (UDI) na região Sul do Brasil. Rev. Bras. Epidemiol. (suppl. Esp) 302:PO690.

Caiaffa, W. T., Mingotti, S. A., Proietti, F. A., Carneiro-Proietti, A. B., Silva, R. C., Lopes, A. C., Doneda, D. (2003). Estimation of the number of injecting drug users attending an outreach syringe-exchange program and infection with human immunodeficiency virus (HIV) and hepatitis C virus: the AjUDE-Brasil project. J. Urban Health 80(1):106-114.

Carvalho, H. B., Mesquita, F., Massad, E., Bueno, R. C., Lopes, G. T., Ruiz, M. A., Burattini, M. N. (1996). HIV and infections of similar transmission patterns in a drug injectors community of Santos, Brazil. J. Acquir. Immune Defic. Syndr. Hum. Retrovirol. 12(1):84-92.

CDC (Centers for Disease Control and Prevention). (1999). Resurgent Bacterial Sexually Transmitted Disease Among Men Who Have Sex with Men-King County, Washington, 1997-1999. Morb. Mortal. Wkly. Rep. 48, United States: U. S. Dept. of Health, Education, and Welfare, Public Health Service, 773-777.

CDC (Centers for Diseases Control and Prevention). (2001). Soft Tissue Infections among Injection Drug Users-San Francisco, California, 1996-2000. Morb. Mortal. Wkly. Rep. 50, United States: U.S. Dept. of Health, Education, and Welfare, Public Health Service, 381-384.

Chitwood, D. D., Comerford, M., Kitner, K. R., Palacios, W., Sanches, J. A. (2001). A comparison of HIV risk behaviors between new and long-term injection drug users. Subst. Use Misuse 36(1-2): 91-111.

Choopanya, K., Des Jarlais, D. C., Vanichseni, S., Kitayaporn, D., Mock, P. A., Raktham, S., Hireanras, K., Heyward, W. L., Sujarita, S., Mastro, T. D. (2002). Incarceration and risk for HIV infection among injection drug users in Bangkok. J. Acquir. Immune Defic. Syndr. 29(1):86-94.

Des Jarlais, D. C., Friedman, S. R., Perlis, T., Chapman, T. F., Sotheran, J. L., Paone, D., Monterroso, E., Neaigus, A. (1999). Risk behavior and HIV infection among new drug injectors in the era of AIDS in New York City. J. Acquir. Immune Defic. Syndr. Hum. Retrovirol. 20(1):67-72.

Doherty, M. C., Garfein, R. S., Monterroso, E., Brown, D., Vlahov, D. (2000). Correlates of HIV infection among young adult short-term injection drug users. AIDS 14(6):717-726. 
Dolan, K., Rutter, S., Wodak, A. D. (2003). Prison-based syringe exchange programmes: a review of international research and development. Addiction 98(2):153-158.

Dourado, I., Andrade, T., Farias, A., Galvao-Castro, B. (2002). In Changing patterns of HIV-I and HTLV-I/II seroprevalence among IDUs from different districts of Salvador, Brazil: effectiveness of prevention strategies? In: Gatell, J. M., Casabona, J., eds. Abstract Book. In: XIV International AIDS Conference; Barcelona, Spain, July, 7-12. Barcelona: Fundació Barcelona SIDA 2002/IAS, MoPeC3423, July7-12117 pp.

Estebanez, P., Zunzunegui, M. V., Aguilar, M. D., Russell, N., Cifuentes, I., Hankins, C. (2002). The role of prison in the HIV epidemic among female injecting drug users. AIDS Care 14(1):95-104.

Ferreira, M. M., Ferrazoli, I., Palaci, M., Salles, P. S., Medeiros, L. A., Novoa, P., Kiefer, C. R., Schechtmann, M., Kritski, A. L., Johnson, W. D., Riley, L. W., Ferreira, O. C. (1996). Tuberculosis and HIV infection among female inmates in Sao Paulo, Brazil: a prospective cohort study. J. Acquir. Immune Defic. Syndr. Hum. Retrovirol. 13(2):177-183.

Friedman, S. R., Aral, S. (2001). Social networks, risk-potential networks, health, and disease. J. Urban Health 78(3):411-418.

Friedman, S. R., Des Jarlais, D. C., Neaigus, A., Abdul-Quader, A., Southern, J. L., Sufian, M., Tross, S., Goldsmith, D. (1989). AIDS and the new drug injector. Nature 339(6223):333-334.

Friedman, S. R., Des Jarlais, D. C., Jose, B., Neaigus, A., Goldstein, M. (1994). Seroprevalence and the history of HIV epidemic among drug injectors. In: Nicolosi, A., ed. HIV Epidemiology: Models and Methods. New York: Raven Press, pp. 137-150.

Friedman, S.R., Jose, B., Deren, S., Des Jarlais, D. C., Neaigus, A. (1995). Risk factors for human immunodeficiency virus seroconversion among out-oftreatment drug injectors in high and low seroprevalence cities. Am. J. Epidemiol. 142(8):864-874.

Friedman, S. R., Friedmann, P., Telles, P. R., Bastos, F. I., Bueno, R., Mesquita, F., Des Jarlais, D.C. (1998). New injectors and HIV-1 risk. In: Stimson, G., Des Jarlais, D. C., Ball, A., eds. Drug Injecting and HIV Infection: Global Dimensions and Local Responses. London: UCL Press, pp. 76-90.

Friedman, S. R., Curtis, R., Neaigus, A. (1999). Social Networks, Drug Injectors' Lives, and HIV/AIDS. Dordrecht: (AIDS Prevention and Mental Health) Kluwer Press.

Fuller, C. M., Vlahov, D., Ompad, D. C., Shah, N., Arria, A., Strathdee, S. A. (2002). High-risk behaviors associated with transition from illicit noninjections to injection drug use among adolescent and young adult drug users: a case-control study. Drug Alcohol Depend 66(2):189-198.

Garfein, R. S., Valverde, R., Swartzendruber, A., Des Jarlais, D. C., Kerndt, P., Morse, E., Oullet, L., Strathdee, S. A., Vlahov, D., Williams, I. T., Monterroso, E. R. (2002). In Differences in correlates of HIV, hepatitis B virus $(H B V)$ and hepatitis $C$ virus ( $H C V$ ) infections among young, streetrecruited injection drug users (IDUs) in United States metropolitan areas. In: Gatell, J. M., Casabona, J., eds. Abstract Book. In: XIV International AIDS Conference; Barcelona: Spain, July 7-12. Barcelona: Fundació Barcelona SIDA 2002/IAS, MoPeC3403, July112 pp. 
Guimaraes, M. L., Bastos, F. I., Telles, P. R., Galvao-Castro, B., Diaz, R. S., Bongertz, V., Morgado, M. G. (2001). Retrovirus infections in a sample of injecting drug users in Rio de Janeiro City, Brazil: prevalence of HIV-1 subtypes, and co-infection with HTLV-I/II. J. Clin. Virol. 21(2):143-151.

Gyarmathy, A.V., Neaigus, A., Miller, M. (2002). In Increased sexual risk among women who recently initiated drug injecting. In: Gatell, J. M., Casabona, J., eds. Abstract Book. In: XIV International AIDS Conference; Barcelona, Spain, July 7-12. . Barcelona: Fundació Barcelona SIDA 2002/IAS, MoPeC3398, July111 pp.

Hagan, H., Thiede, H. (2002). Young injectors: excess risk behaviour without increased risk of seroconversion. In: Gatell, J. M., Casabona, J., eds. Abstract Book. XIV International AIDS Conferences, Barcelona, Spain, July 7-12. Barcelona: Fundació Barcelona SIDA 2002/IAS, MoPeC3403, 129 pp.

Lowndes, C. M., Bastos, F. I., Giffin, K. M., Vaz dos Reis, A. C., d'Orsi, E., Alary, M. (2000). Differential trends in mortality from AIDS in men and women in Brazil (1984-1995). AIDS 14(9):1269-1273.

Maslow, C. B., Friedman, S. R., Perlis, T. E., Rockwell, R., Des Jarlais, D. C. (2002). Changes in HIV seroprevalence and related behaviors among male injection drug users who do an do not have sex with men: New York City, 1990-1999. Am. J. Public Health 92(3):382-384.

Mesquita, F., Kral, A., Reingold, A., Bueno, R., Trigueiros, D., Araújo, P. J. (2001a). Trends of HIV infection among injection drug users in Brazil in the 1990s: the impact of changes in patterns of drug use. J. Acquir. Immune Defic. Syndr. Hum. Retrovirol. 28(3):298-302.

Mesquita, F., Kral, A., Reingold, A., Haddad, I., Sanches, M., Turienzo, G., Piconez, D., Araujo, P., Bueno, R. (2001b). Overdoses among cocaine users in Brazil. Addiction 96(12):1809-1813.

Miller, C. L., Spitall, P. M., Laliberte, N., Li, K., O'Shaughnessy, M. V., Schechter, M. T. (2002). In Risk factors fro HIV and HCV prevalence and incidenc among young injection drug users in a city coping with an epidemic. In: Gatell, J. M, Casabona, J., eds. In: XIV International AIDS Conference; Barcelona, Spain, July 7-12. . Barcelona: Fundació Barcelona SIDA 2002/IAS, MoPeC3401, 112 pp.

Neaigus, A., Friedman, S. R., Jose, B., Goldstein, M. F., Curtis, R., Ildefonso, G., Des Jarlais, D. C. (1996). High-risk personal networks and syringe sharing as risk factors for HIV infection among new drug injectors. J. Acquir. Immune Defic. Syndr. Hum. Retrovirol. 11(5):499-509.

Pechansky, F., von Diemen, L., Kessler, F., Hirakata, V., Metzger, D., Woody, G. E. (2003). Preliminary estimates of human immunodeficiency virus prevalence and incidence among cocaine abusers of Porto Aleger, Brazil. J. Urban Health 80(1):115-126.

Petry, N. M. (2001). Reliability of drug users' self-reported HIV risk behavior using a brief, 11-item scale. Subst. Use Misuse 36(12):1731-1747.

Riley, E. D., Vlahov, D., Huettner, S., Beilenson, P., Bonds, M., Chaisson, R. E. (2002). Characteristics of injection drug users who utilize tuberculosis services at sites of the Baltimore city needle exchange program. J. Urban Health 79(1):113-127.

Souza, C. T., Diaz, T., Sutmoller, F., Bastos, F. I. (2002). The association of socioeconomic status and use of crack/cocaine with unprotected anal sex in 
a cohort of men who have sex with men in Rio de Janeiro, Brazil. J. Acquir. Immune Defic. Syndr. 29(1):95-100.

Szwarcwald, C. L., Bastos, F. I., Gravato, N., Lacerda, R., Chequer, P. N., Castilho, E. A. (1998). The relationship of illicit drug consume to HIVinfection among commercial sex workers (CSWs) in the city of Santos, São Paulo, Brazil. Int. J. Drug Policy 9(6):427-436.

Telles, P. R., Bastos, F. I., Guydish, J., Inciardi, J. A., Surratt, H. L., Pearl, M., Hearst, N. (1997). Risk behavior and HIV seroprevalence among injecting drug users in Rio de Janeiro, Brazil. AIDS 11(suppl. 1):35-42.

Turchi, M. D., Diaz, R. S., Martelli, C. M., Sabino, E. C., Da Silva, W. P., Filho, O. F., Laranjeira, R. R., Busch, M. P., Castelo, A. (2002). Genetic diversity and HIV-1 incidence estimation among cocaine users in Sao Paulo, Brazil. J. Acquir. Immune. Defic. Syndr. 30(5):527-532.

UNAIDS. (2002). AIDS Epidemic Update. http://www.unaids.org/epidemic_update/report_dec01/index.html (accessed March 2003).

Van de Ven, P., Prestage, G., Crawford, J., Grulich, A., Kippax, S. (2000). Sexual risk behaviour increases and is associated with HIV optimism among HIVnegative and HIV-positive gay men in Sydney over the 4 year period to February 2000. AIDS 14(18):2951-2953.

Watters, J. K., Biernacki, P. (1989). Targeted sampling options for the study of hidden populations. Soc. Prob. 36(4):416-430. 


\section{Request Permission or Order Reprints Instantly!}

Interested in copying and sharing this article? In most cases, U.S. Copyright Law requires that you get permission from the article's rightsholder before using copyrighted content.

All information and materials found in this article, including but not limited to text, trademarks, patents, logos, graphics and images (the "Materials"), are the copyrighted works and other forms of intellectual property of Marcel Dekker, Inc., or its licensors. All rights not expressly granted are reserved.

Get permission to lawfully reproduce and distribute the Materials or order reprints quickly and painlessly. Simply click on the "Request Permission/ Order Reprints" link below and follow the instructions. Visit the U.S. Copyright Office for information on Fair Use limitations of U.S. copyright law. Please refer to The Association of American Publishers' (AAP) website for guidelines on Fair Use in the Classroom.

The Materials are for your personal use only and cannot be reformatted, reposted, resold or distributed by electronic means or otherwise without permission from Marcel Dekker, Inc. Marcel Dekker, Inc. grants you the limited right to display the Materials only on your personal computer or personal wireless device, and to copy and download single copies of such Materials provided that any copyright, trademark or other notice appearing on such Materials is also retained by, displayed, copied or downloaded as part of the Materials and is not removed or obscured, and provided you do not edit, modify, alter or enhance the Materials. Please refer to our Website User Agreement for more details.

\section{Request Permission/Order Reprints}

Reprints of this article can also be ordered at http://www.dekker.com/servlet/product/DOI/101081JA200030511 